\title{
Hubungan Orientasi Matlamat, Pemantauan Kendiri Dan Tingkah Laku Kerja Inovatif: Komitmen Afektif Sebagai Pengantara
}

(Relationships between Goal Orientation, Self-Monitoring and Innovative Work Behavior: Affective Commitment as Mediator)

\author{
Norulhuda Tajuddin \\ (UKM-Graduate School of Business, Universiti Kebangsaan Malaysia) \\ (Universiti Teknologi MARA Cawangan Pahang) \\ Rasidah Arshad \\ (Fakulti Ekonomi dan Pengurusan Universiti Kebangsaan Malaysia) \\ Riza Munira Shamsudin \\ (UKM-Graduate School of Business, Universiti Kebangsaan Malaysia) \\ Yusrizal Sufardi Mohd Yunan \\ (UKM-Graduate School of Business, Universiti Kebangsaan Malaysia) \\ (Politeknik METrO Kuala Lumpur, Kementerian Pendidikan Malaysia)
}

\begin{abstract}
ABSTRAK
Objektif utama kajian ini adalah mengkaji kedua-dua hubungan langsung dan tidak langsung antara orientasi matlamat dan pemantauan kendiri dengan tingkah laku kerja inovatif. Secara khususnya, dua dimensi orientasi matlamat-orientasi berasaskan penguasaan (mastery) dan orientasi berasaskan prestasi, dan pemantauan kendiri dihipotesiskan sebagai peramal kepada prestasi inovatif. Dalam masa yang sama, komitmen afektif dihipotesis bertindak sebagai pengantara bagi ketiga-tiga hubungan tersebut. Data dikumpulkan daripada 162 ahli akademik dari institusi pengajian tinggi Malaysia menerusi soalselidik. Pengujian hipotesis dilakukan dengan menggunakan model persamaan berstruktur. Dapatan kajian menunjukkan wujud hubungan langsung yang signifikan bagi orientasi penguasaan dan pemantauan kendiri dengan tingkah laku kerja inovatif. Peranan komitmen afektif sebagai pengantara pula hanya signifikan bagi pemantauan kendiri (pengantara separa) namun didapati tidak mengantara hubungan antara orientasi penguasaan dan orientasi prestasi dengan tingkah laku kerja inovatif.
\end{abstract}

Kata kunci: Orientasi matlamat; pemantauan kendiri; komitmen afektif; tingkah laku kerja inovatif

\section{ABSTRACT}

The objective of the study is to examine both direct and indirect relationships between goal orientations and self-monitoring, and innovative work behavior. Specifically, the two dimensions of goal orientation - mastery and performance orientation, and self-monitoring, were hypothesized to predict innovative work performance, and each relationship is mediated by affective commitment. Data were collected from 162 academicians from higher public education institutions through self-reported questionnaires. The hypothesized relationships were tested using structural equation modelling. The findings demonstrated the significant direct relationships between all the three predictors and innovative work behavior. The indirect relationship via affective commitment as a mediator was only found significant for self- 
monitoring (partial mediation); affective commitment did not mediate the relationship between mastery orientation and performance orientation, and innovative work behavior.

Keywords: Goal orientation; self-monitoring; affective commitment; innovative work behavior

\section{PENGENALAN}

Dalam usaha mencapai kelebihan persaingan dalam persekitaran tempat kerja yang kompleks dan dinamik hari ini, organisasi memerlukan pekerja yang berupaya menyumbang idea dan penyelesaian inovatif dalam melaksanakan kerja atau membuat keputusan (Park, Song, Yoon, \& Kim 2013; Newman, Tse, Schwarz \& Nielsen, 2018). Perbincangan hari ini tidak lagi hanya terumpu kepada persoalan bagaimana untuk menjadi kreatif sahaja tetapi bagaimana untuk menjadi lebih inovatif. Ini kerana keupayaan untuk menghasilkan inovasi menerusi penambahbaikan produk atau perkhidmatan secara berterusan memainkan peranan yang penting dalam memastikan kebolehtahanan sesebuah organisasi dalam jangka panjang. Sebagai contoh, kepentingan inovasi dapat dilihat pada syarikat-syarikat besar seperti Apple, Samsung, Google dan sebagainya yang amat bergantung kepada inovasi untuk memastikan mereka sentiasa terkedepan dalam industri. Justeru, organisasi yang beroperasi berteraskan inovasi boleh meningkatkan kebolehupayaan untuk persaingan, kecekapan dan juga keuntungan (cth. Park et al. 2013; Newman et al. 2018).

Para sarjana mendapati tingkah laku kerja inovatif yang ditunjukkan oleh pekerja berhubung kait dengan kreativiti dalam melaksanakan tugas, dan ini seterusnya akan menghasilkan prestasi terbaik terutamanya bila melibatkan kerja yang kompleks (cth: West 2002; Zhang \& Bartol 2010). Secara umumnya, tingkah laku tersebut bukan hanya tertumpu kepada penerokaan peluang-peluang yang ada dan penghasilan idea baharu, tetapi termasuklah tingkah laku yang diarahkan kepada pelaksanaan perubahan, mengaplikasi pengetahuan baharu atau penambahbaikan prestasi syarikat. Berbanding dengan kreativiti, inovasi merujuk kepada kemampuan seseorang pekerja untuk menjayakan idea kreatif yang diciptakan itu. Menurut West (2002), kreativiti biasanya berlaku di peringkat awal sebelum aktiviti inovasi boleh dicapai. Ini sejajar dengan keperluan dalam melaksanakan tugas yang mana pekerja memerlukan daya fikir yang kreatif untuk menyelesaikan masalah yang dihadapi bagi membolehkan mereka berinovasi dalam kerja mereka (Lee, Tan \& Javalgi 2002). Justeru, sama ada seseorang pekerja itu dikatakan sebagai yang berinovasi atau tidak akan diukur berdasarkan kepada hasil yang mampu dicapai oleh pekerja tersebut dan bukan sekadar pada peringkat menghasilkan idea atau konsep sahaja.

Dapatan kajian lepas yang mengaitkan tingkah laku inovatif dengan prestasi atau hasil kerja telah menarik minat para penyelidik untuk mengenalpasti anteseden yang berpotensi untuk meningkatkan tingkah laku inovasi dalam kalangan pekerja. Antara anteseden yang telah dikaji termasuklah faktor organisasi seperti persekitaran kerja yang inovatif (Liu, Chow, Zhang \& Huang 2017), sistem kerja berprestasi tinggi (Liu et al. 2017) dan persekitaran kerja yang adil (Walumbwa, Cropanzano \& Hartnell, 2009). Selain itu, kajian terhadap faktor individu sebagai peramal kepada tingkah laku inovasi juga mendapat perhatian dalam kalangan penyelidik-penyelidik terdahulu. Antara pemboleh ubah peramal yang didapati signifikan adalah efikasi kendiri (Newman et al., 2018) orientasi matlamat (Lee, Tan \& Javalgi 2010; Zhang \& Kwan 2018) dan personaliti pekerja seperti kehematan (conscientiousness), keterbukaan, proaktif dan kreativiti (cth. Hammond et al. 2011; Wang et al. 2012).

Berbanding dengan faktor persekitaran yang dialami oleh setiap pekerja dalam organisasi terbabit, faktor individu merujuk secara lebih spesifik kepada ciri-ciri, sifat atau sikap yang ada pada seseorang pekerja itu sendiri. Teori perbezaan individu menghujahkan bahawa setiap 
pekerja adalah berbeza dari sudut sifat, personaliti, latar belakang, pengalaman dan sebagainya; dan perbezaan ini secara umumnya berupaya mempengaruhi sikap dan kelakuan pekerja (cth. Lee et al. 2010; Wang et al. 2012; Zhang \& Kwan 2018). Dalam konteks organisasi, misalnya, kemungkinan untuk seseorang pekerja menghasilkan inovasi berbanding pekerja lain yang berkerja dalam persekitaran kerja yang sama boleh dikaitkan dengan faktor perbezaan individu itu sendiri. Tingkah laku inovatif yang ditunjukkan oleh pekerja tersebut mungkin dipengaruhi oleh personaliti atau motivasi dalaman pekerja itu. Hujah ini disokong oleh Hammond et al. (2011) dalam kajian meta-analisis mereka mengenai kepentingan faktor individu sebagai peramal kepada inovasi di tempat kerja. Bukti empirikal juga menunjukkan, walaupun para perkerja berkerja dalam persekitaran kerja yang sama dengan iklim persekitaran kerja yang berinovatif, bukan semua pekerja tersebut mampu mempamerkan kelakuan inovatif (Lu, Lin \& Leung 2012). Hanya beberapa orang sahaja daripada mereka berupaya memberikan hasil kerja inovatif dalam kerja mereka; dan ini berkemungkinan besar boleh dikaitkan dengan faktor perbezaan individu para pekerja itu sendiri. Justeru, berdasarkan kepada bukti empirikal dan kepentingan faktor individu dalam meramal tingkah laku pekerja dalam organisasi, kajian ini akan menyiasat peranan pemboleh ubah motivasi dan personaliti dalam meramal kelakuan kerja inovatif dalam kalangan pekerja. Secara spesifiknya, orientasi matlamat sebagai pemboleh ubah motivasi dan pemantauan kendiri sebagai pemboleh ubah personaliti dicadangkan mempunyai hubungan langsung dengan tingkah laku inovatif. Selain daripada hubungan langsung, kajian ini juga menguji hubungan tidak langsung antara pemboleh ubahpemboleh ubah tersebut dengan tingkah laku inovatif menerusi komitmen afektif sebagai pemboleh ubah pengantara. Pemeriksaan terhadap hubungan tidak langsung adalah penting untuk memahami bagaimana proses hubungan itu berlangsung. Hubungan ini dilihat sebagai relevan kerana komitmen afektif merupakan mekanisme yang berupaya menggerakkan seseorang individu melakukan sesuatu perkara atau mempamerkan sesuatu tingkah laku di tempat kerja.

\section{ULASAN LITERATUR DAN PEMBANGUNAN HIPOTESIS}

\section{ORIENTASI MATLAMAT DAN TINGKAH LAKU KERJA INOVATIF}

Keupayaan untuk melakukan inovasi dan pembaikan secara berterusan merupakan sesuatu yang penting bagi mana-mana organisasi. Menurut Janssen (2001), keupayaan dan kesanggupan pekerja amat diperlukan untuk memastikan inovasi berterusan dapat dicapai oleh sesebuah organisasi. Selain daripada konsepsualisasi berdasarkan pandangan input-output (West 1997), inovasi juga boleh difahami menerusi pendekatan tingkah laku berdasarkan budi bicara yang dikenali sebagai tingkah laku kerja inovatif (Scott \& Bruce 1994). Secara umumnya, tingkah laku kerja inovatif ditakrifkan sebagai tingkah laku individu yang bertujuan untuk memperkenalkan atau mengaplikasikan idea, proses, produk atau prosedur yang baharu dan berguna dalam kerja, unit kerja atau organisasi di mana beliau bekerja (Farr \& Ford 1990) Dengan kata lain, tingkah laku tersebut boleh diterangkan sebagai tingkah laku yang diarahkan untuk menghasilkan, memperkenalkan, dan mengaplikasikan hal-hal baharu yang bermanfaat dalam berbagai peringkat organisasi (West \& Farr 1989). Antara contoh tingkah laku kerja inovatif termasuklah mencari teknologi baharu yang sesuai, mencadangkan cara baharu untuk mencapai objektif, mengaplikasikan kaedah baharu, serta menyiasat dan mendapatkan sumbersumber yang diperlukan untuk melaksanakan idea-idea baharu. Kajian-kajian lepas mengenai inovasi pada tahap individu telah mengkaji peranan motivasi dalaman individu sebagai penentu kepada tingkah laku inovatif di tempat kerja. Salah satu daripada pemboleh ubah motivasi yang 
mendapat perhatian penyelidik adalah orientasi matlamat (Lee et al. 2010; Zhang \& Kwan 2018).

Orientasi matlamat merupakan ciri-ciri pembawaan (disposition) stabil yang ada pada seseorang individu. Ia merujuk kepada kepercayaan seseorang individu mengenai pembangunan kendiri dan bagaimana kepercayaan ini mempengaruhi tafsiran dan penglibatan beliau terhadap persekitaran kerja (Hirst, Van Knippenberg \& Zhou 2009; Zhang \& Kwan 2018). Secara khususnya, orientasi matlamat ditakrifkan sebagai kecenderungan matlamat seseorang individu yang akan menentukan bagaimana beliau mendekati, menterjemahkan dan bertindakbalas kepada pencapaian beliau (Dweck \& Leggett 1988; Hirst et al. 2009; Huang \& Chengchi 2012). Terdapat dua dimensi utama yang digunakan untuk menerangkan dan mengukur orientasi matlamat: orientasi berasaskan penguasaan dan orientasi berasaskan prestasi (Latham 2007: Lee et al. 2006). Menurut teori pencapaian matlamat, kedua-dua jenis pekerja sama ada berorientasikan penguasaan atau berorientasikan prestasi, mempunyai motivasi yang tinggi untuk mencapai matlamat yang telah ditetapkan. Walaupun begitu, terdapat perbezaan dalam motif pembelajaran, tafsiran dan reaksi individu terhadap sesuatu perkara yang berlaku berdasarkan kepada orientasi matlamat yang ada dalam diri; dan ini seterusnya akan mempengaruhi tingkah laku individu tersebut (Elliot 2005).

Orientasi matlamat berasaskan penguasaan merujuk kepada seseorang individu yang membangunkan kompentensi diri dengan cara mendapatkan ilmu pengetahuan dan kemahiran baharu untuk menjadikan diri beliau mahir atau pakar dalam kerja yang mereka lakukan (Kim \& Lee 2013). Menurut teori kognitif sosial, individu yang memiliki orientasi berasaskan penguasaan menimba ilmu dan kemahiran mengenai sesuatu kerja secara praktikal atau mempelajarinya menerusi pemerhatian terhadap apa yang dilakukan oleh pakar (Bandura 1997). Beliau mempunyai kesanggupan untuk sentiasa memperbaiki tingkah laku melalui pembelajaran, cekal untuk berdepan dengan pelbagai situasi sukar, dan percaya bahawa sikap tersebut merupakan ciri penting untuk mereka maju dalam organisasi. Sebagai contoh, pekerja akan berusaha untuk menambahkan ilmu dan kemahiran dengan menghadiri pelbagai latihan yang bertujuan untuk meningkatkan pembangunan kerjaya mereka dan dalam masa yang sama gigih mencari cara bagaimana untuk menambahbaik organisasi. Pandangan ini disokong oleh West (2002) yang mengatakan bahawa kepelbagaian ilmu dan kemahiran yang diperoleh oleh pekerja hasil daripada interaksi antara rakan sepasukan mempengaruhi kemampuan mereka untuk terlibat dalam aktiviti inovasi. Secara empirikal, kajian-kajian lepas telah menemukan hubungan yang signifikan antara orientasi matlamat berasaskan penguasaan dengan tingkah laku inovatif; ilmu dan kepakaran yang diperoleh berupaya meningkatkan penghasilan idea yang inovatif (cth., Ellström 2010; Hirst et al. 2009; Kim \& Lee 2013; Lee et al. 2010; Lu et al. 2012; Zhang \& Kwan 2018).

$\mathrm{H}_{1}$ Terdapat hubungan yang positif antara orientasi matlamat berasaskan penguasaan dan tingkah laku inovatif.

Sementara itu, orientasi matlamat berasaskan prestasi pula merujuk kepada kecenderungan seseorang individu untuk membangunkan kompetensi diri dengan cara mempamerkan kelebihan kompetensi peribadi yang dibandingkan dengan orang lain, dan berusaha untuk mendapatkan penilaian yang positif daripada orang lain (Lin \& Chang 2004). Dengan kata lain, individu yang memiliki orientasi berasaskan pencapaian ini lebih menumpukan usaha untuk menyiapkan tugas yang diberikan dan mendapatkan penilaian yang baik mengenai keupayaan beliau, daripada berusaha membangunkan kemahiran dan kepakaran seperti yang dilakukan oleh individu yang memiliki orientasi berasaskan matlamat.

Kecenderungan golongan individu berorientasikan pencapaian ini boleh dilihat melalui cara mereka mendapatkan penilaian positif tentang keupayaan mereka untuk mencapai 
pertumbuhan peribadi. Pekerja yang berorientasikan pencapaian akan lebih terarah untuk kelihatan cemerlang dan akan sedaya upaya mengelak daripada dilihat sebagai gagal (Maurer \& Lippstreu 2008). Sebagai contoh, dengan kemahiran dan kepakaran yang dimiliki, pekerja akan berusaha bersungguh-sungguh (termasuklah melibatkan diri dengan aktiviti berkaitan inovasi) sebagai cara untuk dikenali dan dihormati oleh rakan-rakan sekerja dan juga ketua kerana ini akan dapat memberikan beliau perasaan bangga dan berjaya dalam organisasi. Bukti empirikal daripada kajian lepas menunjukkan para pekerja yang berorientasikan pencapaian cenderung untuk berusaha dengan bersungguh-sungguh untuk mencapai matlamat, dan ini seterusnya menjadikan mereka mereka lebih cenderung untuk berinovasi (cth. Lee et al. 2010; Sujan, Weitz \& Kumar 1994; Zhang \& Kwan 2018).

$\mathrm{H}_{2}$ Terdapat hubungan yang positif antara orientasi matlamat berasaskan pencapaian dan tingkah laku kerja inovatif.

\section{PEMANTAUAN KENDIRI DAN TINGKAH LAKU INOVATIF}

Pemantauan kendiri merupakan dimensi personaliti yang telah mendapat perhatian para penyelidik dalam bidang tingkah laku organisasi. Pemantauan kendiri boleh didefinisikan sebagai kebolehan seseorang untuk menyesuaikan penampilan dan tingkah laku di khalayak ramai untuk meningkatkan status dan juga memaksimumkan kepentingan kendiri apabila berinteraksi dengan orang lain (Oh et al. 2013). Sesetengah sarjana menggunakan terma "kesan sesumpah" untuk menerangkan keupayaan individu mengubahsuai penampilan kendiri beliau berdasarkan situasi yang dihadapi (cth. Blakely, Andrews \& Fuller 2003; Oh et al. 2013).

Pekerja yang mempunyai personaliti pemantauan kendiri ini biasanya lebih mudah untuk menyesuaikan tindak tanduk mereka dengan mana-mana individu atau pasukan yang berurusan dengan mereka, tanpa mengambil kira ikatan, identifikasi atau penglibatan kumpulan yang sedia ada (Tasselli \& Kilduff 2017; Wang et al. 2012). Kemahiran berinteraksi dengan individu dan pasukan dari pelbagai latar belakang merupakan sesuatu yang penting untuk pekerja memahami proses inovasi. Perkara seumpama ini tidak dapat diperoleh secara mudah seperti mendengar ceramah, tetapi memerlukan pertukaran ilmu pengetahuan dengan pihak lain (Kim \& Lee 2013). Justeru, pekerja yang mempunyai personaliti seperti ini amat relevan di dalam organisasi berteraskan budaya inovasi yang mementingkan kesediaan menghadapi perubahan dan persekitaran yang dinamik.

Menurut teori kognitif sosial (Bandura 1997), jangkaan seseorang individu akan mempengaruhi tingkah laku kerja inovatif kerana ia bertindak sebagai sumber motivasi yang diperlukan untuk tabah menghadapi risiko dan ketidakpastian dalam tindakan yang dilakukan. Justeru, secara teorinya, hubungan antara pemantauan kendiri dengan tingkah laku inovatif wujud kerana ekspektasi individu bahawa apa yang beliau dilakukan dalam usaha menyesuaikan diri dengan keperluan persekitaran akan memberi hasil yang bermanfaat kepada diri sendiri dan organisasi secara keseluruhannya. Ciri-ciri pemantauan kendiri yang tinggi seperti kemampuan untuk berkomunikasi dengan cemerlang, bersikap empati terhadap orang lain, dan mudah menyesuaikan diri menjadikan pekerja merasa lebih berkeyakinan untuk melaksanakan tugas-tugas yang berkaitan dengan innovasi. Selain itu, bukti empirikal daripada kajian lepas juga menunjukkan para pekerja yang mempunyai sifat pemantauan kendiri yang tinggi lebih cenderung untuk mempamerkan keterlibatan kerja, prestasi, dan kemajuan yang tinggi dalam kerja (Day et al. 2002). Justeru, berdasarkan hujah-hujah teori dan empirikal, pemantauan kendiri dijangkakan meramal tingkah laku inovatif di tempat kerja. 
$\mathrm{H}_{3}$ Terdapat hubungan yang positif antara pemantauan kendiri dengan tingkah laku kerja inovatif.

\section{KOMITMEN AFEKTIF SEBAGAI PEMBOLEH UBAH PENGANTARA}

Afektif komitmen merujuk kepada penglibatan, keterikatan pekerja secara emosi terhadap organisasi (Allen \& Meyer 1990). Pekerja yang memberikan komitmen melibatkan emosi selalunya bersedia untuk menyumbang lebih banyak daripada apa yang diharapkan oleh pihak atasan dalam organisasi. Komitmen seperti ini adalah diperlukan daripada pekerja untuk melaksanakan kerja-kerja inovasi yang biasanya melibatkan masa yang lebih panjang, rumit, dan mencabar (Casimir, Lee \& Loon 2012; Montani, Battistelli \& Odoardi 2017). Seseorang pekerja yang memberikan komitmen secara afektif biasanya mempunyai kecekalan untuk menyiapkan sesuatu kerja kerana mereka merasakan kerja itu sebahagian daripada diri mereka. Dengan ini, komitmen afektif amat diperlukan dalam kalangan pekerja dalam proses menghasilkan, dan menjayakan idea terkini dan seterusnya menjadi inovatif di dalam organisasi.

Kajian-kajian lepas telah mengkaji peranan komitmen afektif sebagai pengantara di dalam hubungan peramal-kesan seperti tingkah laku kewargaan organisasi dan tingkah laku tidak produktif (cth. Purba et al. 2015; Ying \& Cohen 2018). Komitmen afektif memainkan peranan yang sangat penting untuk menentukan tingkah laku individu yang ditentukan oleh faktor individu seperti personaliti. Sebagai contoh, Ying dan Cohen (2018) telah mengkaji hubungan antara personaliti-personaliti gelap seperti psychopathy, narcisisme dan Machiavellianism dengan tingkah laku tidak produktif dan mendapati komitmen afektif menjadi pengantara yang signifikan di dalam setiap hubungan tersebut. Sebagai contoh, pekerja yang memiliki sifat narcisisme didapati suka melakukan kerosakan dan tidak mempunyai empati terhadap orang lain, dan dilaporkan kurang kecenderungan untuk menunjukkan komitmen secara emosional. Ini seterusnya mengakibatkan pekerja tersebut terlibat dalam tingkah laku tidak produktif (Ying \& Cohen 2018).

Dalam satu kajian lain, Purba et al. (2015) telah melaporkan dua jenis personaliti iaitu kestabilan emosi dan extraversion yang berhubung secara positif dengan tingkah laku kewargaan organisasi melalui komitmen afektif sebagai pengantara. Pekerja yang mempunyai emosi yang stabil menunjukkan sikap yang mudah mesra, berkeyakinan dan positif apabila berinteraksi dengan rakan sekerja, dan lebih mudah untuk memberikan komitmen afektif kepada organisasi. Situasi ini seterusnya mempengaruhi mereka untuk terlibat dalam tingkah laku kewargaan organisasi. Dapatan yang sama ditemui bagi pekerja yang mempunyai personaliti extraversion yang tinggi. Pekerja tersebut didapati mudah bergaul, mempunyai komitmen afektif yang tinggi dan seterusnya menjadikan pekerja itu cenderung untuk melibatkan diri dalam tingkah laku kewargaan di organisasi. Oleh itu, dengan menggunakan hujah-hujah yang sama, komitmen afektif dicadangkan sebagai pengantara dalam hubungan antara orientasi matlamat (berasaskan penguasaan dan prestasi), dan juga pemantauan kendiri dengan tingkah laku organisasi yang lain seperti tingkah laku kerja inovatif. Antara justifikasi hubungan tersebut adalah seperti berikut.

Pertama, pekerja yang mempunyai orientasi penguasaan yang tinggi lebih cenderung untuk membangunkan kemahiran mereka walaupun mengambil masa yang lama ( $\mathrm{Lu}$ et al. 2012; Kim \& Lee 2013; Lee et al. 2010). Tambahan pula, mereka ini tidak hanya menyasarkan keputusan akhir semata-mata tetapi turut mengambilkira semua aspek pekerjaan kerana mereka percaya bahawa menguasai kemahiran adalah lebih penting untuk mencapai kejayaan. Mereka juga mampu menunjukkan ketekunan semasa berdepan dengan perkara yang sukar dalam pekerjaan, dan ini membolehkan mereka memberikan komitmen secara afektif kepada kerja 
mereka. Seterusnya ini dapat meningkatkan kebarangkalian mereka untuk membangunkan dan melaksanakan idea dan produk yang inovatif (cth. Hirst et al. 2009; Kim \& Lee 2013).

Kedua, pekerja yang memiliki orientasi berasaskan prestasi pula lebih cenderung mengharapkan penilaian yang baik berdasarkan prestasi mereka, dan seboleh-bolehnya cuba untuk mengelakkan sebarang kegagalan dalam melaksanakan kerja. Pekerja yang memiliki orientasi seperti ini akan lebih mudah untuk menunjukkan komitmen secara afektif kepada organisasi kerana pencapaian adalah amat penting kepada mereka. Mereka akan berusaha bersungguh-sungguh untuk berjaya dan kadang-kala dilihat seperti ingin mengalahkan rakan sekerja mereka dalam melaksanakan tugas mereka. Sikap sebegini akan membuatkan mereka terikat kepada organisasi secara emosi, dan seterusnya ikatan tersebut berupaya untuk meningkatkan tingkah laku inovatif di tempat kerja.

Akhir sekali, pekerja yang memiliki pemantauan kendiri yang tinggi akan menunjukkan kebolehan untuk berdepan dengan perubahan yang memerlukan elemen emosi yang tinggi (Wang et al. 2012). Untuk mendepani perubahan-perubahan yang ada, mereka perlu memahirkan diri dan menyesuaikan diri dengan persekitaran terutama sekali hubungan dengan rakan sekerja (Blakely, Andrews \& Fuller 2003; Oh et al. 2013). Pekerja yang memiliki pemantauan kendiri yang tinggi turut memiliki komitmen afektif yang tinggi juga, dan ini seterusnya akan mempengaruhi mereka untuk menjadi lebih inovatif dalam organisasi. Berdasarkan perbahasan di atas, hipotesis-hipotesis berikut dibina untuk mewakili peranan pengantara komitmen afektif dalam hubungan antara faktor peramal dengan tingkah laku kerja inovatif.

$\mathrm{H}_{4}$ Komitmen afektif mengantara hubungan antara orientasi matlamat berasaskan penguasaan dengan tingkah laku kerja inovatif.

$\mathrm{H}_{5}$ Komitmen afektif mengantara hubungan antara orientasi matlamat berasaskan prestasi dengan tingkah laku kerja inovatif.

$\mathrm{H}_{6}$ Komitmen afektif mengantara hubungan antara pemantauan kendiri dengan tingkah laku kerja inovatif.

\section{KAEDAH KAJIAN}

\section{RESPONDEN DAN PROSEDUR PENGUMPULAN DATA}

Kajian ini menggunakan kaedah pengumpulan data melalui soal selidik di atas talian iaitu Google Form. Pautan soal selidik tersebut, yang disasarkan kepada ahli akademik yang berkhidmat di universiti-universiti awam di Malaysia sebagai responden, dihantar melalui alamat emel yang diperoleh daripada laman web universiti. Pemilihan ahli akademik sebagai responden adalah adalah besesuaian dengan bidang kerja ahli akademik bukan hanya terhad kepada tugas-tugas memberi syarahan semata-mata tetapi juga turut melibatkan aktiviti-aktiviti penyelidikan dan perundingan yang memerlukan mereka terlibat dengan tingkah laku berinovasi dalam kerja yang dilakukan. Kerja penyelidikan yang membabitkan sama ada kajian di peringkat asas atau teori dan juga penghasilan produk juga adalah dikira sebagai hasil inovasi yang mana dinilai dalam prestasi kerja tahunan mereka.

Borang soal selidik ini turut disertakan dengan surat yang memaklumkan objektif soal selidik di samping mengingatkan responden bahawa maklumbalas mereka adalah dijamin kerahsiaannya. Soal selidik ini disediakan dalam Bahasa Inggeris dan terbahagi kepada dua (2) bahagian yang mana Bahagian A adalah penyataan-penyataan untuk mengukur pemboleh ubah yang terlibat dan Bahagian B adalah berkenaan dengan demografi responden seperti umur, jantina dan status jawatan. 
Seramai 162 orang ahli akademik telah menjawab soal selidik ini secara atas talian. Dalam kalangan 162 responden tersebut, $77.2 \%$ adalah wanita, $62.3 \%$ responden berumur sekitar 30 hingga 39 tahun, diikuti dengan $24.1 \%$ berumur dari 40 hingga 49 tahun. Sebanyak $82.7 \%$ daripada responden memiliki ijazah sarjana dan $95.7 \%$ daripada mereka berkhidmat secara sepenuh masa di universiti masing-masing.

\section{PENGUKURAN KONSTRUK}

Semua konstruk kajian diukur dengan menggunakan instrumen yang telah dibangunkan oleh penyelidik terdahulu dan telah digunakan secara meluas di dalam bidang kajian tingkah laku organisasi.

Orientasi matlamat diukur menggunakan instrumen diadaptasi daripada Janssen dan Van Yperen (2004). Sebanyak sebelas item digunakan untuk mengukur kostruk ini, antaranya adalah "Saya mendapatkan ilmu pengetahuan baharu atau mempelajari kemahiran baharu dengan bekerja keras". Manakala, lapan item digunakan bagi mengukur orientasi pencapaian. Salah satu penyataan itu berbunyi "Prestasi saya lebih baik daripada daripada prestasi rakan kerja lain”. Responden diminta memilih tahap perseujuan mereka terhadap penyataan yang diberikan dengan menggunakan skala 1 (sangat tidak bersetuju) hingga 7 (sangat bersetuju) mata Likert.

Pemantauan kendiri pula diukur menggunakan skala 18-item yang adaptasi daripada Snyder dan Gangestad (1986). Antara item adalah "Saya mempunyai kebolehan untuk mengawal bagaimana saya menemui orang lain; ia bergantung kepada apa tanggapan yang saya mahu berikan kepada mereka". Instrumen ini mengukur tahap pemantauan kendiri menggunakan skala Likert 7-mata, dengan1 (sangat tidak bersetuju) dan 7 (sangat bersetuju).

Komitmen Afektif diukur menggunakan skala 6-item yang dibangunkan oleh Meyer, Allen, dan Smith (1993). Contoh item adalah "Saya merasa gembira untuk menghabiskan seluruh kerjaya saya dengan organisasi di mana saya bekerja sekarang”. Skala Likert 7-mata dengan nilai 1 = "sangat tidak setuju" hingga nilai 7 = "sangat setuju" digunakan sebagai pengukur konstruk ini.

Tingkah laku kerja inovatif diukur menggunakan skala 9-item yang diadaptasi daripada skala Janssen dan Van Yperen, (2004). Antara penyataan yang terdapat dalam instrument ini adalah "Saya selalu menghasilkan idea baharu untuk penambahbaikan". Kesemua penyataan diukur menggunakan skala tujuh mata Likert dengan skala 1 (sangat tidak bersetuju) hingga 7 (sangat bersetuju).

\section{DAPATAN KAJIAN}

Permodelan Persamaan Berstruktur (Structural Equation Modeling) menggunakan perisian AMOS, dengan prosedur dua-langkah (Anderson \& Gerbing, 1988) telah dijalankan untuk menguji hipotesis kajian. Dalam langkah pertama, model pengukuran penuh dengan petunjuk nyata (manifest indicators) diuji dari segi kesahan dan kebolehpercayaan. Manakala, dalam langkah kedua pula, pengujian dilakukan terhadap model berstuktur penuh untuk menentukan sama ada hipotesis diterima atau ditolak. Beberapa indeks telah dipilih untuk menilai sama ada model diterima sebagai mempunyai padanan yang baik atau pun tidak: Chi-Square, Comparative Fit Index (CFI), Tucker-Lewis Index (TLI), Standardised Root Mean Square residual (SRMR), dan Root-Mean-Square Error of Approximation (RMSEA). Oleh kerana 
bilangan nisbah sampel kepada parameter tidak mencapai tahap yang dicadangkan (Bentler 1995), teknik "parcelling" di mana item asal bagi setiap konstruk digabungkan secara rawak menjadi tiga atau empat item bagi setiap faktor telah dijalankan sebelum penilaian model dilakukan (Bagozzi \& Heatherton 1994).

\section{MODEL PENGUKURAN}

Model pengukuran seperti yang dicadangkan oleh penyelidik menunjukkan nilai indeks padanan yang baik serta memenuhi kriteria yang dicadangkan oleh para sarjana (Hair et al. 2010): Chi-Square $(\chi 2)=138.02, d f=80$ pada $p \leq 0.001$; $\mathrm{RMSEA}=.06$; $\mathrm{SRMR}=.07$; $\mathrm{TLI}=.96$; $\mathrm{CFI}=.97$. Nilai standardized coefficient bagi semua indikator, secara statistiknya, adalah signifikan dan mempunyai nilai antara .83 hingga .95 ; dan ini membuktikan setiap instrumen pengukuran mempunyai kesahan konvergen (convergent validity) yang baik. Seterusnya perbandingan model alternatif menerusi ujian perbezaan Chi-square dijalankan untuk memastikan kesahan diskriminan bagi instrumen pengukuran. Seperti yang ditunjukkan dalam Jadual 1, perbezaan atau pembaikan pada nilai Chi-square yang signifikan dengan nilai $p \leq$ 0.001, dan indeks fit yang semakin baik bagi Model 5-faktor apabila dibandingkan dengan setiap model alternatif lain membuktikan bahawa semua konstruk kajian mempunyai kesahan diskriminan yang baik.

JADUAL 1. Ujian perbezaan Chi-Square bagi model pengukuran

\begin{tabular}{|c|c|c|c|c|c|c|c|c|}
\hline Model & $\chi^{2}$ & $d f$ & $\Delta \chi^{2}$ & $\Delta d f$ & RMSEA & SRMR & TLI & CFI \\
\hline $\begin{array}{l}\text { Model 5-faktor } \\
\text { (Model kajian) }\end{array}$ & 697.12 & 364 & - & - & .06 & .08 & .91 & .92 \\
\hline $\begin{array}{l}\text { Model 3-faktor } \\
\text { (gabungkan semua } \\
\text { pemboleh ubah tidak } \\
\text { bersandar menjadi satu) }\end{array}$ & 711.58 & 366 & $14.47 * *$ & 2 & .06 & .08 & .91 & .92 \\
\hline $\begin{array}{l}\text { Model 2-faktor } \\
\text { (gabungkan semua } \\
\text { pemboleh ubah tidak } \\
\text { bersandar dan } \\
\text { pemboleh ubah } \\
\text { pengantara sebagai } \\
\text { satu) }\end{array}$ & 887.03 & 365 & $189.91 * * *$ & 1 & .08 & .24 & .87 & .88 \\
\hline $\begin{array}{l}\text { Model 1-faktor } \\
\text { (gabungkan semua } \\
\text { pemboleh ubah sebagai } \\
\text { satu) }\end{array}$ & 887.03 & 365 & $189.91 * * *$ & 1 & .08 & .24 & .87 & .88 \\
\hline
\end{tabular}

Nota: $\mathrm{N}=162 ; * * p \leq 0.01 ; * * * p \leq 0.001$.

Jadual 2 menunjukkan keputusan statistik deskriptif untuk pemboleh ubah bersandar dan pemboleh ubah tidak bersandar. Keputusan analisa ini menunjukkan hubungan korelasi seperti yang telah dijangkakan. Semua pemboleh ubah-pemboleh ubah menunjukkan hubungan korelasi yang signifikan dengan nilai $p \leq 0.01$ Jadual 2 juga mempamerkan keputusan kebolehpercayaan Cronbach's Alpha yang baik bagi setiap konstruk dengan nilai antara .82 hingga 95 . 
JADUAL 2. Min skor, ralat piawai, korelasi dan kebolehpercayaan

\begin{tabular}{lccccccc}
\hline Pemboleh ubah & Min & SD & 1 & 2 & 3 & 4 & 5 \\
\hline $\begin{array}{l}\text { 1. Komitmen afektif } \\
\text { 2. Tingkah laku }\end{array}$ & 4.9 & .83 & $(0.86)$ & & & & \\
$\quad$ kerja inovatif & 4.8 & 1.3 & $0.53^{* *}$ & $(0.95)$ & & & \\
$\begin{array}{l}\text { 3. Pemantauan } \\
\quad \text { kendiri }\end{array}$ & 4.8 & .67 & $0.37^{* *}$ & $0.57^{* *}$ & $(0.82)$ & & \\
$\begin{array}{l}\text { 4. Orientasi } \\
\text { penguasaan }\end{array}$ & 5.8 & .73 & $0.29^{* *}$ & $0.44^{* *}$ & $0.39^{* *}$ & $(0.93)$ & \\
5. Orientasi prestasi & 4.3 & 1.3 & $0.27^{* *}$ & $0.31^{* *}$ & $0.34^{* *}$ & $0.31^{* *}$ & $(0.92)$ \\
\hline
\end{tabular}

Catatan: $n=162 ; * * p<0.01$; Nilai kebolehpercayaan $\alpha$ dalam kurungan

\section{MODEL BERSTRUKTUR}

Kesahan dan kebolehpercayaan model pengukuran yang baik membolehkan pengujian hipotesis dijalankan dalam langkah yang seterusnya. Hubungan langsung dan tidak langsung menerusi pombolehubah pengantara diuji menggunakan kaedah bootstrapping dengan 10,000 persampelan semula. Indeks fit bagi model berstruktur menunjukkan fit model yang baik: Chisquare $(\chi 2)=697.116 ; d f=364$ dengan nilai $p \leq 0.001$; $\mathrm{RMSEA}=.06, \mathrm{SRMR}=.08, \mathrm{TLI}=.91$, $\mathrm{CFI}=.92$. Rajah 1 menunjukkan nilai pekali terpiawai (standardized coefficient) bagi setiap hubungan antara pemboleh ubah-pemboleh ubah dalam model kajian. Hasil ujian mendapati hubungan langsung yang signifikan antara pemantauan kendiri dengan tingkah laku inovatif $(\beta=0.34, p \leq 0.001)$; orientasi penguasaan dengan tingkah laku inovatif $(\beta=0.39, p \leq 0.001)$; dan komitmen afektif dengan tingkah laku inovatif $(\beta=0.16, p \leq 0.05)$. Sebaliknya, hubungan antara orientasi prestasi dan tingkah laku kerja inovatif pula adalah tidak signifikan $(\beta=0.15, p$ $\leq 0.05$ ). Bagi hubungan langsung antara pemboleh ubah bebas dan pengantara (komitmen afektif) pula, hanya hubungan antara pemantauan kendiri dan komitmen afektif yang signifikan pada nilai $\beta=0.20, p \leq 0.05$.

Akhir sekali, bagi kesan tidak langsung, dapatan kajian menunjukkan kesan yang signifikan hanya berlaku dalam hubungan antara pemantauan kendiri dengan tingkah laku kerja inovatif $(\beta=0.03, p \leq 0.05)$; manakala dua lagi hubungan tidak langsung tidak menunjukkan kesan yang signifikan. Hubungan yang signifikan ini dipaparkan dalam Jadual 3, di mana hasil ujian bootstrapping bias-corrected 95\% menunjukkan sela keyakinan (confident interval) hubungan tidak langsung antara pemantauan kendiri dan tingkah laku kerja inovatif menerusi afektif komitmen bagi kedua-dua had LLCI dan ULCI yang tidak mengandungi nilai sifar (.003; .094). Secara keseluruhan model kajian menerangkan sebanyak $49 \%$ varian dalam tingkah laku kerja inovatif. 


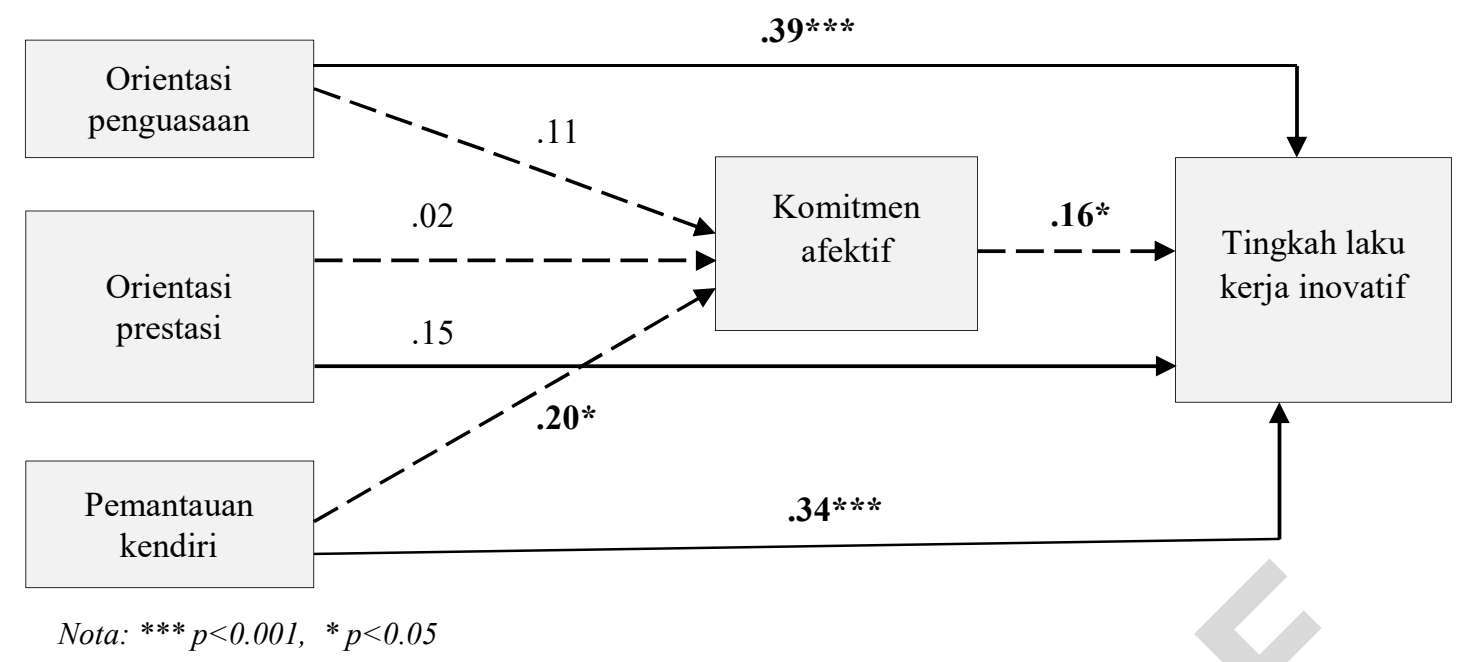

RAJAH 1. Model berstruktur dan coefficient bagi setiap hubungan antara pemboleh ubah kajian

JADUAL 3. Hasil pengujian hipotesis hubungan langsung dan tidak langsung

\begin{tabular}{|c|c|c|c|c|c|}
\hline \multirow[b]{2}{*}{ Hipotesis } & \multirow[b]{2}{*}{ Coefficient } & \multirow[b]{2}{*}{ Nilai-p } & \multicolumn{2}{|c|}{ Bootstrapped 95\% CI } & \multirow[b]{2}{*}{ Keputusan } \\
\hline & & & Bawah(LLCI) & Atas(ULCI) & \\
\hline $\begin{array}{l}\mathrm{H}_{1} \text { : Orientasi matlamat berasaskan } \\
\text { penguasaan meramal tingkah } \\
\text { laku kerja inovatif }\end{array}$ & .39 & .00 & .21 & .57 & Disokong \\
\hline $\begin{array}{l}\mathrm{H}_{2} \text { : Orientasi matlamat berasaskan } \\
\text { prestasi meramal tingkah laku } \\
\text { kerja inovatif }\end{array}$ & .15 & .08 & -.02 & .31 & $\begin{array}{l}\text { Tidak } \\
\text { disokong }\end{array}$ \\
\hline $\begin{array}{c}\mathrm{H}_{3} \text { : Pemantauan kendiri meramal } \\
\text { tingkah laku kerja inovatif }\end{array}$ & 3 & .00 & .20 & .49 & Disokong \\
\hline $\begin{aligned} \mathrm{H}_{4}: & \text { Komitmen afektif mengantara } \\
& \text { hubungan antara orientasi } \\
& \text { matlamat berasaskan } \\
& \text { penguasaan dan tingkah laku } \\
& \text { kerja inovatif }\end{aligned}$ & .02 & .18 & -.08 & .07 & $\begin{array}{l}\text { Tidak } \\
\text { disokong }\end{array}$ \\
\hline $\begin{aligned} \mathrm{H}_{5}: & \text { Komitmen afektif mengantara } \\
& \text { hubungan antara orientasi } \\
& \text { matlamat berasaskan prestasi } \\
& \text { dan tingkah laku kerja inovatif }\end{aligned}$ & .003 & .75 & -.04 & .04 & $\begin{array}{l}\text { Tidak } \\
\text { disokong }\end{array}$ \\
\hline $\begin{aligned} \mathrm{H}_{6}: & \text { Komitmen afektif mengantara } \\
& \text { hubungan antara pemantauan } \\
& \text { kendiri dan tingkah laku kerja } \\
& \text { inovatif }\end{aligned}$ & .03 & .02 & .003 & .09 & Disokong \\
\hline
\end{tabular}

\section{PERBINCANGAN}

Kajian ini menyiasat peranan pemboleh ubah motivasi dan personaliti dalam meramal tingkah laku kerja inovatif dalam kalangan ahli akademik di institusi pengajian tinggi di Malaysia, dan peranan komitmen organisasi sebagai pengantara dalam hubungan tersebut. Pemboleh ubah 
motivasi diwakili oleh orientasi matlamat berasaskan penguasaan dan orientasi matlamat berasaskan prestasi, manakala pemboleh ubah personaliti pula diwakili oleh pemantauan kendiri. Dapatan kajian menunjukkan dua pemboleh ubah peramal, iaitu orientasi matlamat berasaskan penguasaan dan pemantauan kendiri mempengaruhi tingkah laku inovatif secara positif. Ini bermaksud pekerja yang mempunyai sama ada orientasi penguasaan, atau pemantauan kendiri yang tinggi mempunyai kecenderungan yang tinggi untuk mempamerkan tingkah laku kerja inovatif di tempat kerja.

Seperti yang dibincangkan sebelum ini, pekerja yang berorientasikan penguasaan sentiasa berusaha meningkatkan kecekapan dan kemahiran berkaitan kerja. Selaras dengan penerangan teori kognitif sosial (Bandura 1997), ketekalan individu dalam menimba ilmu dan kemahiran menjadikan beliau yakin dengan kebolehan untuk melaksanakan tugas dengan berkesan. Selain itu ilmu dan kepakaran yang diperoleh juga menjadikan beliau lebih cenderung untuk mengemukakan idea-idea yang kreatif dan inovatif umtuk pembaikan organisasi. Secara empirikal, dapatan kajian ini juga konsisten dengan kajian-kajian lepas yang melaporkan ilmu dan kepakaran yang ditimba oleh individu berorientasikan penguasaan berupaya meningkatkan tingkah laku inovatif di tempat kerja (cth. Ellström 2010; Kim \& Lee 2013; Lee et al. 2010; Zhang \& Kwan 2018).

Bagi pemantauan kendiri pula, konsisten dengan dapatan kajian lepas (Day et al. 2002), individu yang dicirikan sebagai berkebolehan mengadaptasi diri dan tingkah laku mengikut kesesuaian keadaan didapati mempunyai kecenderungan yang tinggi untuk mempamerkan tingkah laku inovatif di tempat kerja. Ini kerana kebolehan menyesuaikan diri menjadikan pekerja lebih berkeyakinan untuk melibatkan diri dengan aktiviti berkaitan inovasi organisasi seperti pencetusan idea, inovasi produk, dan penambah baikan produktiviti dan prestasi organisasi. Perkara seumpama ini tidak sukar untuk dilaksanakan oleh pekerja yang memiliki pemantauan kendiri yang tinggi kerana personaliti yang dimiliki membolehkan beliau menghadapi perubahan besar dalam organisasi yang melibatkan aktiviti-aktiviti kerja berinovasi dalam organisasi.

Selain hubungan secara langsung, kajian ini juga mengkaji hubungan tidak langsung dengan menyiasat peranan komitmen afektif sebagai pengantara dalam hubungan antara pemboleh ubah peramal dan kesan. Dapatan daripada kajian ini menunjukkan peranan komitmen afektif sebagai pengantara yang signifikan dalam hubungan antara pemantauan kendiri dan tingkah laku kerja inovatif. Hubungan ini boleh dijelaskan oleh personaliti pekerja dengan pemantauan kendiri yang mudah untuk menyesuaikan diri terutamanya dalam hubungan sosial dan hubungan antara perorangan. Ciri-ciri ini berupaya meningkatkan komitmen emosi pekerja kepada organisasi, dan seterusnya ikatan emosi ini menjadikan pekerja lebih cenderung melibatkan diri dengan tingkah laku kerja inovatif. Dapatan ini konsisten dengan kajian-kajian terdahulu yang membuktikan kepentingan komitmen afektif sebagai pemboleh ubah pengantara dalam hubungan peramal dan kesan (cth. Lee et al. 2010; Ying \& Cohen 2018).

Bertentangan dengan apa yang telah dijangkakan oleh penyelidik, terdapat tiga hubungan yang tidak signifikan dalam kajian ini: i) hubungan langsung antara orientasi prestasi dengan tingkah laku inovatif; dan ii) hubungan tidak langsung antara kedua-dua orientasi penguasaan dan orientasi prestasi menerusi komitmen afektif sebagai pengantara.

Hubungan antara orientasi pencapaian dan tingkah laku kerja inovatif yang tidak signifikan mungkin boleh dijustifikasi berdasarkan ciri-ciri yang dimiliki oleh pekerja berorientasikan pencapaian itu sendiri. Secara teorinya, pekerja berorientasikan pencapaian terlalu menitikberatkan pandangan atau penilaian positif daripada orang lain dalam apa jua perkara yang mereka lakukan. Ini mungkin akan menyebabkan mereka terlalu menumpukan kepada kemahiran dan kecekapan sedia ada sehingga mereka tidak menyedari berlakunya perubahan dalam persekitaran yang memerlukan ilmu pengetahuan dan kemahiran baharu. Kegagalan 
dalam mengemaskini ilmu dan kemahiran tersebut mungkin meyebabkan pekerja tidak berminat dengan aktiviti berkaitan inovasi di tempat kerja. Selain itu, dapatan ini juga membuktikan bahawa kedua-dua dimensi dalam orientasi matlamat iaitu orientasi penguasaan dan orientasi pencapaian adalah konstuk yang berbeza (cth. Kim \& Lee 2013). Pekerja yang mempunyai orientasi matlamat yang berbeza, sama ada mereka mementingkan penguasaan kepada kemahiran dan ilmu pengetahuan atau matlamat untuk mencapai prestasi yang tinggi, akan mempengaruhi tingkah laku mereka untuk melibatkan diri dalam aktiviti inovasi.

Bagi hubungan tidak langsung pula, kegagalan kajian ini dalam membuktikan peranan komitmen afektif sebagai pengantara dalam hubungan antara orientasi matlamat berasaskan penguasaan dan orientasi berasaskan prestasi dengan tingkah laku kerja inovatif boleh dijelaskan oleh pemboleh ubah peramal ketiga iaitu pemantauan kendiri yang bertindak. Jika dilihat kepada hubungan korelasi, ketiga-tiga pemboleh ubah peramal didapati mempunyai hubungan yang signifikan dengan komitment afektif. Walau bagaimanapun, apabila ketiga-tiga pombolehubah tersebut dimasukkan dan diuji secara bersama dalam satu model, hubungan antara orientasi penguasaan dan orientasi prestasi dengan tingkah laku inovatif telah berubah menjadi tidak signifikan, manakala hubungan antara pemantauan kendiri masih lagi kekal signifikan. Ini menunjukkan hubungan yang kuat antara pemantauan kendiri dengan komitmen afektif yang telah mengambil alih kesan orientasi matlamat terhadap komitmen afektif.

Secara praktikalnya, dapatan kajian ini meningkatkan lagi kefahaman berkaitan hubungan antara orientasi matlamat dan pemantauan kendiri dengan dengan tingkah laku kerja inovatif terutamanya dalam konteks institusi pengajian tinggi. Faktor perbezaan individu terutamanya motivasi dan personaliti mempengaruhi kecenderungan seseorang ahli akademik untuk melibatkan diri dengan tingkah laku inovatif di tempat kerja. Organisasi secara amnya, dan universiti secara khusus, terutamanya yang berorientasikan inovasi, perlu memahami dan mengambil kira kepentingan perbezaan individu dalam pengambilan pekerja termasuklah ahli akademik, dan dalam menyediakan program latihan dan pembangunan untuk mereka. Pihak pentadbiran universiti misalnya, perlu melabur dalam program yang boleh meningkatkan tingkah laku kerja yang disesuaikan secara spesifik mengikut perbezaan individu sama ada dari segi orientasi matlamat dan personaliti. Walau bagaimanapun, bergantung kepada pemilihan pekerja berdasarkan kepada orientasi matlamat dan personaliti semata-mata tidak menjamin berlakunya inovasi dalam organisasi. Perkara yang tidak kurang pentingnya adalah menyediakan suasana atau persekitaran yang kondusif dan memudahkan mereka untuk menimba ilmu pengetahuan dan kemahiran yang dapat membantu mereka lebih berdaya kreatif dan melakukan aktivit-aktiviti berkaitan inovasi. Pembelajaran akan lebih mudah untuk berlaku apabila pemimpin aktif menjadi contoh kepada ahli akademik dan dalam masa yang sama meyakinkan ahli akademik untuk sama-sama berusaha menghasilkan dan melaksanakan idea dan inovasi dalam organisasi terutamanya di universiti.

\section{BATASAN DAN CADANGAN}

Dapatan kajian ini harus ditafsir dengan mengambilkira beberapa limitasi. Pertama, kajian ini dijalankan menggunakan persampelan bukan berkebarangkalian, maka hasil kajian tidak seharusnya digeneralisasi untuk mewakili populasi ahli akademik di Malaysia. Kajian masa akan hadapan disarankan untuk menggunakan sampel pekerja yang berbeza. Kedua, kajian ini dijalankan secara keratan rentas yang mana dapatan kajian ini tidak mungkin berupaya memberi gambaran yang menyeluruh mengenai konstruk dan hubungan sebab dan kesan yang dikaji. Oleh itu, kajian masa hadapan perlu dilakukan secara longitudinal untuk menangani limitasi ini. Akhir sekali, kajian ini bergantung sepenuhnya terhadap kaji selidik kuantitatif. Oleh itu, kajian kualitatif perlu dilakukan agar dapat menerangkan dan menyokong dapatan kajian ini dengan lebih terperinci. Akhir sekali, berdasarkan kepada dapatan kajian ini 
mengenai kepentingan faktor individu dalam meramal tingkah laku kerja inovatif, kajian masa depan dicadangkan untuk menyiasat peranan faktor perbezaan individu lain seperti nilai kerja dan orientasi nilai budaya terutamanya dalam kerangka hubungan pengantara-penyederhana.

\section{REFERENCES}

Allen, N.J. \& Meyer, J.P. 1990. The measurement and antecedents of affective, continuance and normative commitment to the organization. Journal of Occupational Psychology, 63(1): 1-18.

Anderson, J.C. \& Gerbing, D.W. 1988. Structural equation modeling in practice: A review and recommended two-step approach. Psychological Bulletin 103(3): 411-423.

Bagozzi, R.P. \& Heatherton, T.F. 1994. A general approach to representing multifaceted personality construct. Structural Equation Modeling 1: 35-67.

Bandura, A. 1997. Self-Efficacy: The Exercise of Control. New York: Freeman

Bentler, P.M. 1995. On the fit of models to covariances and methodology. Psychological Bulletin 112: 400-404.

Blakely, G.L., Andrews, M.C. \& Fuller, J. 2003. Are chameleons good citizens? A longitudinal study of the relationship between self- monitoring and organizational citizenship behavior. Journal of Business \& Psychology 18(2): 131-144.

Casimir, G., Lee, K. \& Loon, M. 2012. Knowledge sharing: Influences of trust, commitment and cost. Journal of Knowledge Management 16(5): 740-753.

Day, D.V., Schleicher, D.J., Unkless, A.L. \& Hiller, N.J. 2002. Self-monitoring personality at work: A meta-analytic investigation of construct validity. Journal of Applied Psychology 87(2): 390-401.

Dweck, C.S. \& Leggett, E.L. 1988. A social cognitive approach to motivation and personality. Psychological Review 95(2): 256-273.

Elliot, A.J. 2005. A conceptual history of the achievement goal construct. Handbook of Competence and Motivation 16: 52-72.

Ellström, P. E. 2010. Practice-based innovation: A learning perspective. Journal of Workplace Learning 22(1/2): 27-40.

Farr, J.L. \& Ford, C.M. 1990. Individual innovation. In Innovation and Creativity at Work: Psychological and Organizational Strategies, edited by M.A. West \& J.L. Farr, 63-80. Oxford, England: John Wiley \& Sons.

Hair, J.F., Black, W.C., Babin, B.J. \& Anderson, R.E. 2010. Multivariate Data Analysis. 7th edition. New York: Pearson.

Hammond, M.M., Neff, N.L., Farr, J.L., Schwall, A.R. \& Zhao, X. 2011. Predictors of individual-level innovation at work: A meta-analysis. Psychology of Aesthetics, Creativity, and the Arts 5(1): 90-105.

Hirst, G., Van Knippenberg, D. \& Zhou, J. 2009. A cross-level perspective on employee creativity: Goal orientation, team learning behavior, and individual creativity. Academy of Management Journal 52(2): 280-293.

Huang, J.-C. \& Chengchi, N. 2012. The relationship between conflict and team performance in Taiwan: The moderating effect of goal orientation. The International Journal of Human Resource Management 23: 37-41.

Janssen, O. 2001. Fairness perceptions as a moderator in the curvilinear relationships between job demands, and job performance and job satisfaction. Academy of Management Journal 44(5): 1039-1050.

Janssen, O. \& Van Yperen, N.W. 2004. Employees' goal orientations, the quality of leadermember exchange, and the outcomes of job performance and job satisfaction. Academy of Management Journal 47(3): 368-384. 
Kim, T.T. \& Lee, G. 2013. Hospitality employee knowledge-sharing behaviors in the relationship between goal orientations and service innovative behavior. International Journal of Hospitality Management 34(1): 324-337.

Latham, G.P. 2007. Work motivation: History, Theory, Research, and Practice. Thousand Oaks, CA: Sage

Lee, C., Hui, C., Tinsley, C.H. \& Niu, X. 2006. Goal orientations and performance: Role of temporal norms. Journal of International Business Studies 37(4): 484-498.

Lee, O.F., Tan, J.A. \& Javalgi, T.R. 2010. Goal orientation and organizational commitment: Individual difference predictors of job performance. International Journal of Organizational Analysis 18(1): 129-150.

Lin, S. \& Chang, J. 2004. Goal orientation and organizational commitment as explanatory factors of employees ' mobility. Personnel Review 34(3): 331-353.

Liu, F., Chow, I. H.-S., Zhang, J.-C. \& Huang, M. 2017. Organizational innovation climate and individual innovative behavior: exploring the moderating effects of psychological ownership and psychological empowerment. Review of Managerial Science 13: 1-19.

Lu, L., Lin, X. \& Leung, K. 2012. Goal orientation and innovative performance: The mediating roles of knowledge sharing and perceived autonomy. Journal of Applied Social Psychology 42: 180-197.

Maurer, T.J. \& Lippstreu, M. 2008. Who will be committed to an organization that provides support for employee development? Journal of Management Development 27: 328-347.

Meyer, J.P., Allen, N.J. \& Smith, C.a. 1993. Commitment to organizations and occupations: Extension and test of a three-component conceptualization. Journal of Applied Psychology 78(4): 538-551.

Montani, F., Battistelli, A. \& Odoardi, C. 2017. Proactive goal generation and innovative work behavior: The moderating role of affective commitment, production ownership and leader support for innovation. Journal of Creative Behavior 51(2): 107-127.

Newman, A., Tse, H.H.M., Schwarz, G. \& Nielsen, I. 2018. The effects of employees' creative self-efficacy on innovative behavior: The role of entrepreneurial leadership. Journal of Business Research 89: 1-9.

Oh, I.-S., Charlier, S.D., Mount, M.K. \& Berry, C.M. 2013. The two faces of high selfmonitors: Chameleonic moderating effects of self-monitoring on the relationships between personality traits and counterproductive work behaviors. Journal of Organizational Behavior 35(1): 92-111.

Park, Y.K., Song, J.H., Yoon, S.W. \& Kim, J. 2013. Learning organization and innovative behavior: The mediating effect of work engagement. European Journal of Training and Development 38(1/2): 75-94.

Purba, D.E., Oostrom, J.K., Van Der Molen, H.T. \& Born, M.P. 2015. Personality and organizational citizenship behavior in Indonesia: The mediating effect of affective commitment. Asian Business and Management 14(2): 147-170.

Snyder, M. \& Gangestad, S. 1986. On the nature of self-monitoring: Matters of assessment, matters of validity. Journal of Personality and Social Psychology 51(1): 125-39.

Sujan, H., Weitz, B.A. \& Kumar, N. 1994. Learning orientation, working smart, and effective selling. Journal of Marketing 58(3): 39-52.

Tasselli, S. \& Kilduff, M. 2017. When Brokerage between Friendship Cliques Endangers Trust: A Personality-Network Fit Perspective. Academy of Management Journal 61(3).

Walumbwa, F.O., Cropanzano, R. \& Hartnell, C.A. 2009. Organizational justice, voluntary learning behavior, and job performance: A test of the mediating effects of identification and leader-member exchange. Journal of Organizational Behavior 30(8): 1103-1126.

Wang, H., Begley, T., Hui, C. \& Lee, C. 2012. Are the effects of conscientiousness on contextual and innovative performance context specific? Organizational culture as a 
moderator. The International Journal of Human Resource Management 23(1): 174-189. West, M. 1997. Innovation and creativity at work. Training, Education and Employment: 2124.

West, M.A. 2002. Sparkling fountains or stanant ponds: An integrative model of creativity and innovation implementation in work groups. Applied Psychology: An International Review 51(3): 355-424.

West, M.A. \& Farr, J.L. 1989. Innovation at work: Psychological perspectives. Social Behaviour 4: 15-30.

Wilkesmann, M. \& Wilkesmann, U. 2017. Industry 4.0 - Organizing routines or innovations? Introduction. VINE Journal of Information and Knowledge Management Systems.

Ying, L. \& Cohen, A. 2018. Dark triad personalities and counterproductive work behaviors among physicians in China. The International Journal of Health Planning and Management 33(4): e985-e998.

Zhang, X. \& Bartol, K.M. 2010. Linking empowering leadership and employee creativity: The influence of psychological empowerment, intrinsic motivation, and creative process engagement. Academy of Management Journal 53(1): 107-128.

Zhang, X. \& Kwan, H.K. 2018. Team learning goal orientation and innovation: Roles of transactive memory system and task interdependence. Journal of Business Management and Administration Affairs 1: 1-10.

Norulhuda Tajuddin

UKM-Graduate School of Business

Universiti Kebangsaan Malaysia

43600 UKM Bangi, Selangor, MALAYSIA.

Universiti Teknologi MARA Cawangan Pahang

Kampus Raub

27600 Raub, Pahang, MALAYSIA.

E-Mail: alhudatajuddin583@pahang.uitm.edu.my

Rasidah Arshad (penulis koresponden)

Fakulti Ekonomi dan Perniagaan

Universiti Kebangsaan Malaysia

43600 UKM Bangi, Selangor, MALAYSIA.

E-Mail: rasida@ukm.edu.my

Riza Munira Shamsudin

UKM-Graduate School of Business

Universiti Kebangsaan Malaysia

43600 UKM Bangi, Selangor, MALAYSIA.

E-Mail: rizamshamsudin@gmail.com

Yusrizal Yunan Mohd Yunan

UKM-Graduate School of Business

Universiti Kebangsaan Malaysia

43600 UKM Bangi, Selangor, MALAYSIA.

E-Mail: yusrizal.yunan@gmail.com 